\title{
Manna in Winter: Indigenous Americans, Huckleberries, and Blueberries
}

\author{
Kim E. Hummer ${ }^{1}$ \\ USDA-ARS National Clonal Germplasm Repository, 33447 Peoria Road, Corvallis, OR 97333-2521
}

Additional index words. highbush blueberry, rabbiteye blueberry, Vaccinium corymbosum

\begin{abstract}
More than 35 species of blueberries (Vaccinium L.) and huckleberries (Vaccinium and Gaylussacia Kunth.) are indigenous to North America. The indigenous North American peoples, wise in the ways of survival, recognized the quality of these edible fruits and revered these plants. Beyond food needs, these plants played significant roles in their culture, sociology, economics, and spirituality. Because these traditions, developed and gathered over millennia, were transmitted orally, documentation of these uses have been determined through archeological data, written records from western civilization after first contact, and recent surveys of present-day native peoples. The wealth of indigenous knowledge on blueberries, huckleberries, and other foods was shared with European immigrants. These fruits were used by many tribes throughout North America. Samuel de Champlain documented that fresh and dried blueberries provided "manna in winter" when other food was scarce. Pemmican, a preserved concoction of lean meat, fat, and blueberries or other fruit, enabled survival. Blueberry products such as ohentaqué, hahique, satar, sakisatar, sautauthig, k'enkash, navag, and nunasdlut'i were important to Native Americans. Roger Williams, Meriwether Lewis, and Henry David Thoreau were each impressed with the uses of blueberries by indigenous Americans. The social, technological, and horticultural changes that gave rise to a commercial wild huckleberry and blueberry gathering and production history are summarized.
\end{abstract}

\section{NORTH AMERICAN BLUEBERRY SPECIES}

Blueberries (Vaccinium) and huckleberries (Gaylussacia and Vaccinium) are members of the Ericaceae (heath family). Vaccinium has a circumboreal distribution but also has many named species native in the South Pacific Islands, South America, and Africa (GRIN, 2012; Vander Kloet, 1988). Vaccinium is distributed across North America (Fig. 1). Species in Vaccinium section Cyanococcus are distributed in the east, whereas those of section Myrtillus are found in the northwestern region (Table 1). The Vaccinium genome is diverse. Species are adapted to northern and southern climates. During the past 100 years, development of blueberry cultivars from wild species has expanded throughout North America with significant production in South America and Europe. Low-chilling southern highbush cultivars ( $V$. corymbosum) have enabled expansion of blueberries into warm environments. In the north, berries from wild stands of native lowbush blueberries (V. angustifolium) are collected annually for commercial and private purposes. In the west, wild stands of huckleberries are red-fruiting relatives, cranberry (V. macrocarpon) and lingonberry ( $V$. vitis-idaea), are cultivated and collected from the wild for conserves, jams, juice, and other products. Vaccinium produces many significant commercial crops (Vander Kloet, 1988).

The focus of this article is to summarize native peoples' historical uses of the $\approx 30$

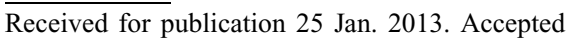
for publication 21 Feb. 2013.

This paper was part of the workshop "A Survey on the Contribution of Indigenous People of North America to Horticulture" held 1 Aug. 2012 at the ASHS Conference, Miami, FL, and sponsored by the History of Horticultural Science Working Group (HIST).

${ }^{1}$ To whom reprint requests should be addressed; e-mail Kim.Hummer@ars.usda.gov.
}

Vaccinium species (Table 1) indigenous to North America, the precursors to our cultivated blueberries. These species include plants that are commonly known as blueberries, huckleberries, whortleberries, bilberries, cranberries, and lingonberries. Some of the taxonomy is complicated because similar plants in the same family have overlapping common names. In the eastern and southern United States, "huckleberry" may refer to plants in the genus Gaylussacia or Vaccinium. In the western United States, at least four Vaccinium species ( $V$. membranaceum, $V$. ovalifolium, $V$. deliciosum, and $V$. caespitosum) are referred to as mountain huckleberries, besides one red-fruited species called "red huckleberry" ( $V$. parvifolium) and the Oregon coastal "black huckleberry" or "evergreen huckleberry" ( $V$. ovatum).

\section{NORTH AMERICAN NATIVE PEOPLES}

In North America, $\approx 550$ tribes reside on 310 reservations in the United States. Reservations are unevenly distributed throughout the country but most are located west of the Mississippi River. Reservation lands were initially designated by treaty from the U.S. government or granted from area in the public domain. The areas of land included in native peoples' reservations are $225,410 \mathrm{~km}^{2}$ (55.7 million acres) representing $\approx 2.3 \%$ of the area of the United States (Wikipedia, 2013). First Nation Reserves in Canada include a total area over 3 million ha (AAA Native Arts, 2013)

Native peoples typically revered nature, lived sustainably, and were cognizant of the interconnected and harmonious aspects of plants, animals, and people (Strass, 2010). Their presence can be documented in western United States more than 11,000 years ago by archeological analysis (Connolly, 1999). Many European explorers and immigrants, oblivious to native peoples' culture and traditions, wrote of them as "savages." Indigenous knowledge was erroneously judged simple and primitive, perhaps as a result of their traditional oral rather than written acquisition and transmission. Throughout the tribes, ethno-botanical plant uses were mainstays of survival. This local indigenous knowledge is important not only for healthy eating for their native human populations, but for medicinal applications and drugs.

The objective of this review is to summarize horticultural implications of the use of Vaccinium blueberries and their relatives by indigenous peoples of North America. Without written records from native peoples, documentation will be presented through archeological data, written records from members of western cultures after first contact, and recent surveys of present-day tribes.

\section{DOCUMENTATION OF NATIVE USE OF HUCKLEBERRY}

Archeological data. During the past 10,000 years, the caldera at Newberry Lake, central Oregon, has been the site of several mafic and silicic eruptions (Jensen and Chitwood, 2000). Also, sections of lakebeds exposed in the sides of the trench of Ana River below Ana Spring near the northwestern corner of Summer Lake basin in Lake County, OR, are revealed near the top at least six layers of pumice. Four of these appear to record eruptions of Mount Mazama that led to the formation of Crater Lake; the source of the fifth is not known; the sixth is attributed to a later eruption of Newberry Crater. Because certain layers in the associated sediments imply shallow water conditions, these eruptions must have occurred when the last pluvial lake, formerly $\approx 215 \mathrm{ft}$ deep, had been reduced by evaporation to a depth of $\approx 85 \mathrm{ft}$, probably $\approx 14,000$ years ago. The data appear to extend back the ages of Mount Mazama pumice, of Crater Lake, and of Paleo-Indian occupation of the area by several thousand years (Allison, 1945).

Pollen and phytolith analysis of sediments from four sites in Newberry Crater 


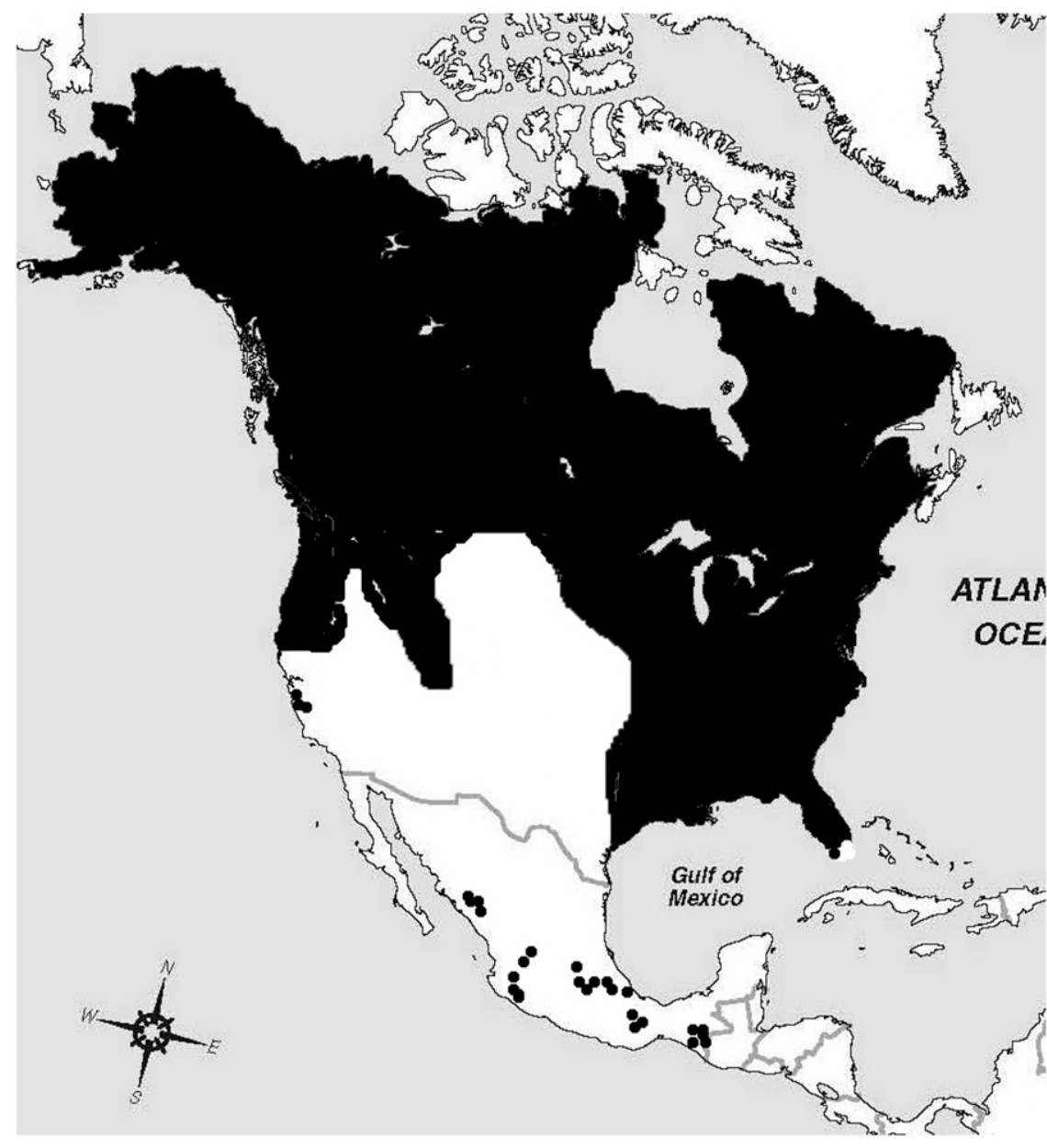

Fig. 1. Distribution of Vaccinium in North America. Compiled from Vander Kloet (1988).

were examined by Cummins (1999). The samples of the sediments represented two pre-Mazama, a post-Mazama, and modern time periods (Cummins, 1999). Paleosols from each of the time periods were examined for pollen and phytoliths. A house, hearth, and pit were also examined. Pollen of several fruit species was observed from each of the sediments. These pollens included chokecherry [Prunus virginiana var. demissa (Nutt.) Torr.], salmonberry (Rubus spectabilis Pursh), thimbleberry (Rubus parviflorus), raspberry (Rubus strigosus L.), and blackberry (species of Rubus section Rubus) as well as huckleberry (Vaccinium spp.) (Cummins, 1999). Ribes L. could have been present as well. These fruits were available and could have been used by native peoples of the region as far back as 11,000 B.P.

First contact. Many of the early European settlers, from many walks of life, in the eastern United States recorded native peoples' use of blueberries, huckleberries, or whortleberries [Thoreau, ex Dean, 2000 (Table 2)]. Samuel de Champlain, the founder of Quebec, was the first to record this activity in 1615 , five years before the Pilgrims crossed the Atlantic (Thoreau, ex Dean, 2000). Champlain observed a gathering of Algonquin women as they dried "blues" in the sun. $\mathrm{He}$ noted that they prepared a kind of bread of pounded, sifted cornmeal, mixed with boiled, mashed beans, and then added the dried blueberries. The blueberries provided "manna in winter" when other food was scarce. In 1643, Roger Williams, an English Protestant theologian and founder of the Providence Plantation, was a student of Native American languages. During a voyage to England, he produced Key into the Languages of America published in London in 1643 . He observed that:

Sautaash are these currants [= blueberries or whortleberries] dried by the Natives, and so preserved all the year, which they beat to powder and mingle it with their parched meal, and make a delicious dish which they call Sautauthig, which is as sweet to them as plum or spice cake is to the English (Thoreau, ex Dean, 2000).

In 1743, botanist John Bartram returned to Philadelphia and saw a gathering of Iroquois near Lake Ontario. He described an Indian woman and her children drying huckleberries:

This was done by setting four forked sticks in the ground about three or four feet high then others across. Over them, the stalks of Centurea jacea or
Saratula. On these lie the berries... Underneath she had kindled a smoky fire that her children were tending.

Captain Meriwether Lewis on reaching the Shoshone tribe (which occupied areas east and west of the Rocky Mountains) made the following entry into his travel journal on 15 Aug. 1805:

This morning I arose very early and as hungry as a wolf. I had eaten nothing yesterday except one scant meal of the flour and berries, except the dried cakes of berries, which did not appear to satisfy my appetite as they appeared to do those of my Indian friends. I found on inquire of $\mathrm{McNeal}$ that we had only about two pounds of flour remaining. This I directed him to divide into two equal parts and to cook the one half this morning in a kind of pudding with the berries as he had done yesterday, and reserve the balance for the evening. On this new-fashioned pudding four of us breakfasted, giving a pretty good allowance also to the chief, who declared it the best thing he had tasted for a long time.

Henry David Thoreau, the man who "went to the woods because he wished to live deliberately," was greatly interested in the natural world around him. In Fall 1859, he began to collect phenological lists and charts on many natural seasonal phenomena including migrating birds and the leafing flowering and fruiting of plants (Richards and Alexander, 2006). He prepared and finished a manuscript entitled "Wild Fruits," which he left wrapped, bound in brown paper and string, and placed in a chest. This manuscript in disarray was found in papers donated to collections at the New York Public Library in 1940. Bradley Dean interpreted Thoreau's handwriting, ordered the pages, and published it (Dean, 2000). This manuscript contained not only data on the fruiting of berry crops in the northeastern United States, but Thoreau researched and referenced more than 20 written citations on native peoples' use of blueberries, or whortleberries, as he called them. He concluded that:

...from time immemorial down to the present day, all over the northern part of America, (Indians) have made far more extensive use of the whortleberry at all seasons and in various ways than we, and that they were far more important to them than to us (Thoreau, ex Dean, 2000).

Thoreau claimed that whortleberries were a major Native American food source and indeed, these fruits nourished them through thousands of years of sustainable subsistence existence.

Medicinal applications. Native Americans not only used Vaccinium fruit as a food source, but applied the leaves, stems, flowers, and roots in different preparations for medicinal uses (Vander Kloet, 1988). These plant parts 


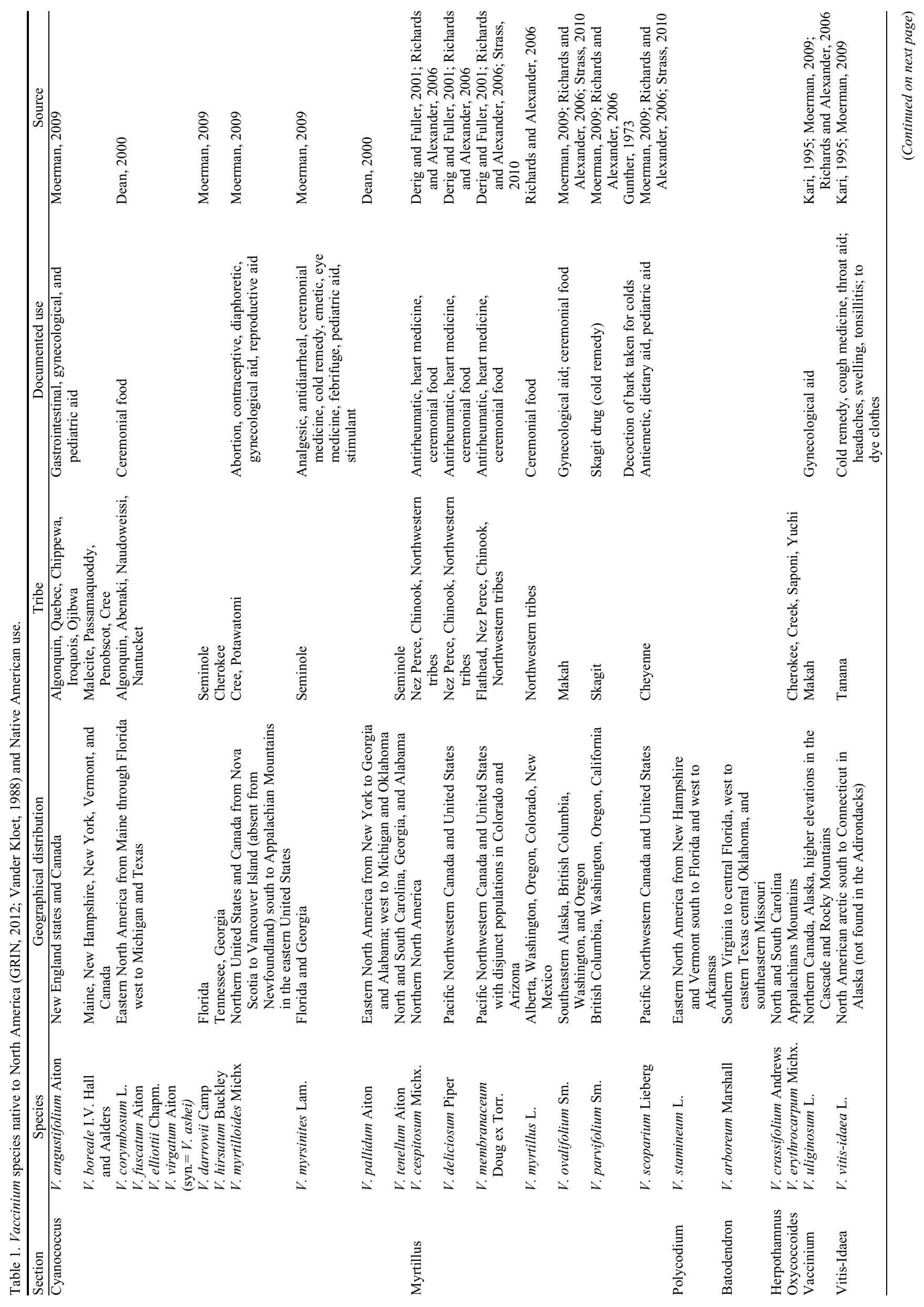


were steeped in hot water to produce teas or infusions. The intended applications included purification of the blood, treating colic in infants, inducing labor, and as a diuretic (Black, 1980; Smith, 1932).

Moerman (2009) prepared a compilation of the medicinal uses of Native American plants by indigenous peoples. This volume could be thought of as a Materia Medica for Native Americans. In this book, 25,000 uses of 2,700 plant species were annotated by more than 217 groups of Native Americans. For Vaccinium, 12 species were described by 14 native peoples (Table 1). Multiple and sometimes conflicting applications were cited for many species' entries.

\section{SURVEYS OF NATIVE PEOPLES}

Social histories have summarized the interaction of Native Americans and the use of Vaccinium (Michell, 2009; Richards and Alexander, 2006; Strass, 2010). Richards and Alexander (2006) reviewed wild huckleberry harvesting by tribes from Pacific Northwestern North America. Michell (2009) reported on community-based research in aboriginal contexts working within the northern Woodlands Cree community and culture. Strass (2010) surveyed living members of the Salish and Kootenai of the Flathead Reservation about huckleberry harvesting. These social and historical reports clearly note that $\mathrm{Vac}$ cinium was more than food and medicine for the Native Americans. These plants had cultural, economic, and spiritual meaning as well. Huckleberries played significant parts in traditional legends. The harvest gathering times were causes of celebration and opportunities to visit friends and relatives not seen since the previous season. This was a traditional time of work to harvest the fruit for use during the rest of the year; however, evenings were reserved for celebration, oral histories, and legends (Strass, 2010).

Present-day berry fields are disappearing in some areas (Richards and Alexander, 2006). The tree canopies have become thicker, and the pioneer Vaccinium plants do not thrive in shade. Where these traditional native berry production areas are present on reservation land or in national parks, native peoples are in discussion with government agencies concerning land use and protocols to improve stand management (Richards and Alexander, 2006; Strass, 2010). Long-term conservation has been an awareness and purpose of action of native peoples.

Huckleberries as a commercial industry. In the late $1800 \mathrm{~s}$, in the western United States, the tribal subsistence activity of gathering blueberries and huckleberries shifted to become a large-scale commercial industry. Canning technology that was invented in France began to be used in the United States (Richards and Alexander, 2006). Although the native peoples dried their berries, the European immigrant settlers brought the Mason jar for home canning into the mountains near the berry fields. By the 1920s, commercial companies for sale of fruits and 
Table 2. Written record of Indigenous People's use of native North American Vaccinium.

\begin{tabular}{|c|c|c|c|c|}
\hline Author & $\mathrm{Yr}$ & Native Peoples & Location & Citation \\
\hline $\begin{array}{l}\text { Samuel B. Champlain, founder } \\
\text { of Quebec }\end{array}$ & 1615 & Algonquin & Near Lake Ontario & (Thoreau ex Dean, 2000) \\
\hline Gabriel Sagard, Franciscan Friar & 1624 & Huron & Near Lake Huron & (Thoreau ex Dean, 2000) \\
\hline Roger Williams & 1643 & Wampanoag and other & Massachusetts & (Dean, 2000) \\
\hline $\begin{array}{l}\text { English Protestant theologian, } \\
\text { Governor }\end{array}$ & & New England Indians & & \\
\hline $\begin{array}{l}\text { Nathanial Morton, secretary of } \\
\text { Plymouth Colony }\end{array}$ & 1669 & $\begin{array}{l}\text { Wampanoag and other } \\
\text { New England Indians }\end{array}$ & Plymouth, MA & (Thoreau ex Dean, 2000) \\
\hline John Josselyn & 1672 & Wampanoag and other & Maine, Massachusetts & (Thoreau ex Dean, 2000; Josselyn, 1672) \\
\hline Gentleman author & & New England Indians & & \\
\hline Captain Benjamin Church & 1676 & $\begin{array}{l}\text { Wampanoag and other } \\
\text { New England Indians }\end{array}$ & New Bedford, MA & (Thoreau ex Dean, 2000) \\
\hline John Bartram, Botanist & 1743 & Iroquois & Lake Ontario & (Thoreau ex Dean, 2000) \\
\hline Meriwether Lewis & 1805 & Shoshone & Montana & Journal 15 Aug. 1805 \\
\hline Henry Perkins & 1843 & Chinookan (Wasco-Wishram) & The Dalles, Columbia River, & (Boyd, 1996) \\
\hline Methodist missionary & & and Sahaptin peoples & Pacific Northwest & \\
\hline Henry D. Thoreau & 1862 & Algonquin, Nantucket & Massachusetts & (Dean, 2000) \\
\hline
\end{tabular}

native berries occurred at Hamilton and Kalispell, MT (Richards and Alexander, 2006). These companies required the harvesting of thousands of pounds of berries to make the commercial venture viable. In 1932, huckleberries were a major crop, with $\approx 1$ MT picked in Montana and slightly less in Washington State (Richards and Alexander, 2006). People began developing rakes, other devices, and techniques to obtain as many berries as possible. Native American and people of European extraction would gather in camps and collect the fruit. The huckleberry industry shrank by the end of World War II as large processors declined. Local roadside stands and a few small processors continued to made jam.

In the 1960 s the ethnicity of pickers changed; non-Native American women and children became the primary harvesters. Poor people, not involved in the logging industry, turned to picking as an occupation. Within 20 years, huckleberry products began to be marked as a local cultural symbol and as a tourist souvenir for visitors. Wild huckleberry products in Montana continue to produce more than $\$ 1$ million in sales revenue annually. Jams, jellies, and preserves account for $\approx 40 \%$ of the production. Native peoples continue to be concerned that the productivity of the blueberry fields has declined over the years with the emphasis on commercial production rather than traditional uses (Strass, 2010).

\section{CONCLUSIONS}

Vaccinium plants and their fruit have played a significant role in the lives of native peoples in North America throughout the millennia. Paleosols from the different time zones in the strata at Newberry Crater in central Oregon confirm Paleo-Indian occupation for more than 10,000 years. The presence of berries was ubiquitous in pre- and postMazama time periods through the present (Connolly, 1999; Cummins, 1999). Written records from first contact with European immigrants confirm the significance that blueberries and their relatives provide as ceremonial and staple food, broadly applied medicines as well as cultural motivation for the committed bonding force of family and tribal activities (Dean, 2000; Moerman, 2009). The Native American knowledge and use of these plants provided food to enable the survival of the European explorers and immigrants in this "new world." The reverence held by the native peoples for these plants promotes community commonwealth and provides examples of sustainable agricultural production. Some crop area of native stands of Vaccinium has reduced berry production, and total area is reduced as a result of human encroachment (Richards and Alexander, 2006). Regulations to protect blueberry crop collection area needs to be enacted for in situ conservation. To paraphrase Thoreau (Dean, 2000), we trust that we may not outlive the last of the huckleberries so our children will always be able to go "a-huckleberrying."

\section{Literature Cited}

AAA Native Arts. 2013. 21 Feb. 2013. <http:// www.aaanativearts.com/canadian_reserves251300.htm>.

Allison, I.S. 1945. Pumice at Summer Lake, Oregon. Geo. Soc. Amer. Bul. 56:789-808.

Black, M.J. 1980. Algonquin ethnobotany: An interpretation of aboriginal adaptation in southwestern Quebec. Can. Ethnology Serv., Paper 65. National Museums of Canada, Ottawa, Ontario, Canada.

Boyd, R. 1996. Peoples of the Dalles, the Indians of Wascopam Mission, University of Nebraska Press. Lincoln. 414 pp.

Connolly, T.J. 1999. Newberry Crater: A tenthousand-year record of human occupation and environmental change in the basinplateau borderlands. Univ. of Utah Anthropological Papers, No. 121. Salt Lake City, UT.

Cummins, L.S. 1999. Pollen and phytolith analysis, p. 202-210. In: Connolly, T.J. (ed.). Newberry crater: A ten-thousand-year record of human occupation and environmental change in the basin-plateau borderlands. Univ. of Utah Anthropological Papers, No. 121. Salt Lake City, UT.

Dean, B.P. (ed.). 2000. Wild fruits: Thoreau's rediscovered lost manuscript. Norton, New York, NY.
Derig, B.B. and M.C. Fuller. 2001. Wild berries of the west. Mountain Press, Missoula, MT.

Gunther, E. 1973. Ethnobotany of western Washington: The knowledge and use of indigenous plants by Native Americans. Revised ed. University of Washington Press, Seattle, WA.

GRIN. 2012. US Department of Agriculture, Agricultural Research Service, National Genetic Resources Program. Germplasm Resources Information Network (GRIN) [online database]. National Germplasm Resources Laboratory, Beltsville, MD. 16 June 2012. $<\mathrm{http} / / /$ www.ars-grin.gov/cgi-bin/npgs/html/tax search.pl>.

Jensen, R.A. and L.A. Chitwood. 2000. Late Holocene uplift of caldera floor, Newberry Crater, Oregon, p. 88-96. In: Friends of the Pleistocene. Pacific Northwest Cell. Deschutes National Forest, Bend, OR. 1 Apr. 2013. <http:// www.wou.edu/las/physci/taylor/eisi/jen_chit_ 01b.pdf>.

Josselyn, J. 1672. New-England's rarities discovered in birds, fishes, serpents, and plants of that country (reprint). Applewood Books, Bedford, MA.

Kari, P.R. 1995. Tanaina plantlore [Dena'ina K'et'una]. Alaska Native Language Center, University of Alaska, Fairbanks. National Park Service. Fairbanks, AK.

Michell, H.J. 2009. Gathering berries in northern contexts. PhD diss., First Nations University of Canada, Regina, Saskatchewan, Canada.

Moerman, D.E. 2009. Native American medicinal plants: An ethnobotanical dictionary. Timber Press, Portland, OR.

Richards, R.T. and S.J. Alexander. 2006. A social history of wild huckleberry harvesting in the Pacific Northwest. Gen. Tech. Rep. PNWGTR-657. U.S. Department of Agriculture, Forest Service Pacific Northwest Research Station, Portland, OR.

Smith, H.H. 1932. Ethnobotany of the Ojibwe Indians. Bul. Public Mus. Milwaukee 4:327525 .

Strass, K. 2010. Huckleberry harvesting of the Salish and Kootenai of the Flathead Reservation. UNDERC West: Practicum in field biology. University of Notre Dame, Dept. of Biology, Land O'Lakes, WI.

Vander Kloet, S.P. 1988. The genus Vaccinium in North America. Research Branch, Agriculture Canada, Ottawa, Ontario, Canada.

Wikipedia. 2013. Indian reservations. $21 \mathrm{Feb}$. 2013. <http://en.wikipedia.org/wiki/Indian_ reservation>. 